\title{
O LULISMO E AS CLASSES SOCIAIS NA POLÍTICA DO BRASIL CONTEMPORÂNEO ${ }^{1}$
}

\author{
Angelo Girotto Neto ${ }^{2}$
}

\begin{abstract}
Resumo
O presente artigo se propõe a uma revisão bibliográfica da produção de alguns dos principais teóricos brasileiros da atualidade acerca do tema do lulismo, relacionando-o à dinâmica das classes sociais e suas expressões políticas e ideológicas. O objetivo que aqui pretende-se é esclarecer os aspectos estruturais que interagem historicamente para dar curso ao contexto político contemporâneo do país, onde se postula a emergência de uma "nova classe média". No âmbito da luta de classes, busca-se apontar como os interesses e a visão de mundo da classe trabalhadora se expressam na política, confrontando a hipótese da emergência de uma "nova classe média". A análise caminha no sentido de postular a dinamização da classe trabalhadora sob o lulismo, compreendendo seus limites e potenciais. Busca contribuir, desta forma, para a compreensão da influência do percurso da classe trabalhadora brasileira sob o lulismo nos processos políticos em curso.
\end{abstract}

Palavras-chave: política brasileira, lulismo, nova classe média.

\section{Resumen}

El presente artículo se propone a una revisión bibliográfica de la producción de algunos de los principales teóricos brasileños da la actualidad sobre el lulismo, en relación con la dinámica de las classes sociales y sus expressiones políticas y ideológicas. El objetivo és aclarar los aspectos estruturales que interactúan historicamente para dar curso al contexto político contemporáneo del país, donde se postula la aparición de una "nueva clase media". Dentro de la lucha de clases, se busca apontar como los intereses y la visión de mundo de la clase obrera se expressa en la política, confrontando la hipótesis de la aparición de una "nueva clase media". El análisis camina hacia postular la dinámica de la clase obrera bajo el lulismo, coprendendo sus límites y potenciales. Busca contribuir, así, a la comprensión de la influencia de la ruta de la clase obrera brasileña bajo el lulismo en los procesos políticos en curso.

Palabras clave: política brasileña, lulismo, nueva clase media.

\begin{abstract}
This article proposes a bibliographic review on the production of some major Brazilian theorists on the subject of Lulism, as related to the dynamics of social classes and their political and ideological expressions. The objective is to explain the structural aspects that historically interact to provide contemporary political context of the country, where it is postulated the rise of a "new middle class". In the context of the class struggle, we try to point out how the interests and the point of view of the working class is expressed in politics, analyzing the hypothesis of the rise of a "new middle class". The analysis moves towards to postulate the dynamics of the working class under
\end{abstract}

\footnotetext{
1 Este artigo resulta das pesquisas para a dissertação A Voz das Ruas e a Rearticulação da Ideologia Conservadora, em curso sob a orientação do Prof ${ }^{\circ}$ Dr. José Antônio Spineli Lindozo, do PPGCS/UFRN, a quem agradeço pelos inestimáveis apoio e inspiração.

${ }^{2}$ Mestrando no Programa de Pós-Graduação em Ciências Sociais da Universidade Federal do Rio Grande do Norte (PPGCS/UFRN) e membro do Grupo de Pesquisas ECO - Estudos em Comunicação Organizacional - da UFRN.
} 
Lulism, including its limitations and potentials. The objective is to contribute to the understanding of the influence of the Brazilian working class route under Lulism in political processes underway.

Keywords: Brazilian politics, Lulism, new middle class.

\section{OS SENTIDOS DO LULISMO EM DISPUTA}

Dentro do amplo debate acerca do significado histórico e prático do lulismo, serão destacadas neste trabalho as três das correntes que aqui se julga centrais, cujas visões do lulismo pode-se assim expressar: uma primeira visão que identifica no lulismo um novo populismo ao estilo peronista; uma outra que vê nele uma regressão conservadora que visa a desmobilizar o proletariado; e, noutro espectro ideológico, temos a visão de um lulismo baseado em um reformismo brando e na conciliação de classes.

Uma das correntes mais relevantes de interpretação do lulismo, em seus contornos atuais, é a inaugurada por Francisco de Oliveira (2003; 2010), afirmando-se como uma expressão das mais lúcidas dentre as forças opositoras ao lulismo pelo espectro ideológico da esquerda. Oliveira vê na ascensão do lulismo o avesso da hegemonia, o exercício da direção do Estado por um grupo político oriundo das classes subalternas a serviço da consecução dos projetos de interesse da classe dominante. O lulismo, em sua visão, constitui um bloco conservador, de caráter regressivo, que desarticula a luta dos trabalhadores e reforça o programa neoliberal de exploração máxima do trabalho via pacificação da classe trabalhadora e cooptação de suas lideranças.

Essa linha interpretativa tem em Ruy Braga seu mais produtivo discípulo. Seguindo os passos de Oliveira, Braga defende que, no lulismo,

a essência consiste em combinar o consentimento passivo das massas - que, seduzidas pelas políticas públicas redistributivas e pelos modestos ganhos salariais advindos do crescimento econômico, aderiram momentaneamente ao governo - com o consentimento ativo das direçôes sindicais - seduzidas por posições no aparato estatal, fora as incontáveis vantagens materiais proporcionadas pelo controle dos fundos de pensão (BRAGA, 2012, p. 37).

Para Braga, nas décadas de 70 e 80 do século passado, em substituição ao sindicalismo populista herdado da Era Vargas, teria entrado em cena um novo sindicalismo - que representaria a superação dialética do anterior na medida em que o negaria enraizado na mobilização política de um crescente precariado, e, que, posteriormente, o assimilaria conservadoramente ao ascender ao governo num processo de "transformismo" 
- conceito gramsciano em que grupos dirigentes de classes ou frações de classes aliadas ou subalternas são recrutados para o exercício da direção política e moral da sociedade mediante a adesão ao projeto da classe dominante no modo de produção. "Negação do sindicalismo populista, o novo sindicalismo negou sua própria negação ao assumir a direção do modelo de desenvolvimento pós-fordista no país, cuja reprodução supõe a pacificação da política do precarido" (ibid, p. 230).

Ainda seguindo os passos de Oliveira, Braga admite a hipótese de que tal transformismo se cristalize no surgimento de "uma 'nova classe' social no país baseada na articulação da camada mais elevada de administradores de fundos de previdências complementar com a elite da burocracia sindical participante dos conselhos de administração desses mesmos fundos." (ibid, p. 23-24) Oliveira vê aí o nexo explicativo da manutenção da política macroeconômica de FHC nos primeiros anos do governo Lula, para a qual inclusive foi recrutado um quadro das fileiras do PSDB, o então presidente do Banco Central Henrique Meirelles (OLIVEIRA, 2003).

O que Braga chama de "arqueologia da hegemonia lulista" estaria na "relação social politicamente pragmática enraizada no consentimento ativo das direções sindicais à liderança de Lula da Silva combinada com a pacificação, por meio da negociação de pequenas concessões aos trabalhadores, do ânimo combativo das bases." (BRAGA, 2012, p. 227)

$\mathrm{Na}$ base desse processo, o autor destaca o protagonismo de uma fração de classe: o precariado. O precariado seria a parcela do proletariado caracterizada por sua inserção precária no mercado de trabalho. Baixos salários, alta rotatividade, qualificação profissional insignificante são suas marcas distintivas. Seu contingente principal são os jovens em busca do primeiro emprego. O precariado é a base social do que Braga chama de classismo em estado prático, "uma relação política baseada em interesses materiais enraizados na estrutura de classes, ainda que carente de recursos organizativos, ideológicos e políticos” (ibid, p. 37).

As condições materiais da ascensão do precariado no Brasil se situam na dinâmica das economias capitalistas periféricas, nas quais a reprodução e acumulação do capital, atravancadas pela necessária contração do valor pago pela força de trabalho, engendram um ciclo vicioso, no qual a menor capacidade de consumo das massas trabalhadoras acarreta em menor estímulo à produção industrial, tornando mais atrativos os investimentos em serviços e sobretudo na especulação financeira e nos fundos públicos.

A precarização é uma necessidade acentuada no capitalismo tardio. Diz Braga: “entendemos que em decorrência da mercantilização do trabalho, do caráter capitalista da 
divisão do trabalho e da anarquia da reprodução do capital, a precariedade é constitutiva da relação salarial" (ibid, p. 17). Daí o diagnóstico de que "considerando os limites impostos ao modo de regulação pela inserção dependente do país na divisão internacional do trabalho, o fordismo periférico frustrou as principais expectativas despertadas pela promessa de superação do subdesenvolvimento.” (ibid, p. 35).

A crise do paradigma fordista teria sérias implicações sobre o precariado: "excluído da cidadania fordista e a meio caminho entre a sedução autoritária e o resgate pelas políticas públicas, o precariado alcançou o centro da agenda política europeia" (ibid, p. 16). Esse fenômeno estaria , de acordo com as análises de Robert Castel, na base do resgate de ideologias conservadoras e anti-imigracionistas na Europa.

No Brasil, o marco da constituição das relações pós-fordistas de trabalho se deu nos umbrais da década de 90:

a vitória eleitoral de Fernando Collor, em 1989, representou a transição para a regulação neoliberal: a partir de então, o próprio regime de acumulação transformou-se em objeto de sucessivos ajustes estruturais que, ao fim e ao cabo, asseguraram o nascimento do pós-fordismo financeirizado no país. (ibid, p. 23).

É nesse contexto que o lulismo surge como opção transformista para o prosseguimento do atual estágio de acumulação pós-fordista financeirizada. O lulismo, amparado no Partido dos Trabalhadores e na Central Única dos Trabalhadores, que outrora foram para os movimentos de ruptura do proletariado as "forças sociais que haviam ajudado a levantá-los", agora seria o agente de sua desestruturação. "Ao alimentar o mito da superação da crise por meio do aumento constante do consumo popular engendrado pela racionalização das políticas públicas federais, a regulação lulista despolitizou a classe trabalhadora" (ibid, p. 226).

$\mathrm{Da}$ necessidade do capitalismo periférico brasileiro reproduzir as condições econômicas e políticas de "produção do trabalho barato", surge o lulismo como solução transformista visando arrefecer os conflitos de classe, desmobilizar o proletariado e garantir condições pacíficas para o exercício da máxima exploração, mediante pequenas concessões. Em suas próprias palavras, o papel histórico do lulismo assim se define:

[...] para pilotar o modelo de desenvolvimento pós-fordista no país sem romper com o ciclo da valorização financeira só mesmo pacificando as fontes do trabalho barato, daí uma modesta desconcentração de renda na base da pirâmide salarial a fim de garantir uma severa concentração de capital financeiro no cume do regime de acumulação (ibid, p. 225). 
Assim, Braga corrobora a tese de que o lulismo representaria a consecução de um projeto conservador, que busca desmobilizar o proletariado e suas frações, sendo, portanto, o grande desafio das forças de transformação da sociedade a sua superação.

Engajado nesse projeto, em seus estudos sobre os operadores de telemarketing da cidade de São Paulo, Braga teria percebido o embrião de um "instinto reformista plebeu", ainda que inconsciente ou reprimido, que "já ameaça mostrar-se impaciente com o conformismo daqueles que se deixaram transformar em instrumentos do atual modelo de desenvolvimento." E em tom de conclusão afirma:

Embora carente de recursos programáticos, organizativos, ou mesmo ideológicos, esse instinto começa a se manifestar nas greves e nas mobilizações do setor, pressionando o sindicalismo lulista a incorporar suas demandas que, lentamente, vão se tornando mais ofensivas. Desafiando o coro dos contentes, não seria nenhuma surpresa encontrar, em um futuro próximo, esses trabalhadores alinhados aos batalhões vanguardistas da luta de classes (ibid, p. 230).

Qual não deve ter sido sua satisfação, um ano depois da publicação de Política do Precariado, ao ver multidões acorrendo às ruas? Dada a conclusão de seus estudos, foi natural para Braga ver nos Movimentos de Junho de 2013 o estopim da mobilização do precariado:

\begin{abstract}
Se os grupos pauperizados que dependem do Programa Bolsa Família e os setores organizados da classe trabalhadora que em anos recentes conquistaram aumentos acima da inflação ainda não entraram na cena política, o "precariado" - a massa formada por trabalhadores desqualificados e semiqualificados que entram e saem rapidamente do mercado de trabalho, por jovens à procura do primeiro emprego, por trabalhadores recém saídos da informalidade e por trabalhadores subremunerados - está nas ruas manifestando sua insatisfação com o atual modelo de desenvolvimento. (BRAGA, 2013, p. 82).
\end{abstract}

Estaríamos "diante de um autêntico processo de mobilização do proletariado precarizado em defesa tanto de seus direitos à saúde e à educação públicas e de qualidade quanto pela ampliação de seu direito à cidade", onde a "questão da efetivação e ampliação dos direitos sociais é a chave para interpretarmos a maior revolta popular da história brasileira" (ibid, p. 82). Por mais que Braga se dedique de forma produtiva a sondar na realidade brasileira os elementos dinâmicos capazes de portar um projeto político transformador, ele não chega demonstrar como esses pressupostos agiram sobre os Movimentos de Junho de 2013. 
Enquanto Braga vê no precariado o agente social portador das condições necessárias para superar progressivamente o lulismo, que seria um bloco de poder conservador, Fernando Henrique Cardoso encontra nas classes médias e em novos agentes a força social capaz de promover a realocação dos grupos dirigentes no comando do Estado brasileiro.

O ex-presidente parte de pressupostos similares aos de Oliveira e Braga acerca do lulismo, chegando a conclusões diversas que servem de orientação a seu campo político, conforme podemos conferir na análise de seu artigo O papel das oposições (CARDOSO, 2011):

Enquanto o PSDB e seus aliados persistirem em disputar com o PT influência sobre os "movimentos sociais" ou o "povão", isto é, sobre as massas carentes e pouco informadas, falarão sozinhos. Isto porque o governo "aparelhou", cooptou com benesses e recursos as principais centrais sindicais e os movimentos organizados da sociedade civil e dispõe de mecanismos de concessão de benesses às massas carentes mais eficazes do que a palavra dos oposicionistas, além da influência que exerce na mídia com as verbas publicitárias.

Quanto às alternativas de uma oposição ao lulismo afirma:

Sendo assim, dirão os céticos, as oposições estão perdidas, pois não atingem a maioria. Só que a realidade não é bem essa. Existe toda uma gama de classes médias, de novas classes possuidoras (empresários de novo tipo e mais jovens), de profissionais das atividades contemporâneas ligadas à ti (tecnologia da informação) e ao entretenimento, aos novos serviços espalhados pelo Brasil afora, às quais se soma o que vem sendo chamado sem muita precisão de "classe c" ou de nova classe média.

Mais adiante, Cardoso defende que é através das redes sociais que as oposições podem dialogar com esse público mais inclinado ao conteúdo de seu projeto. Ele argumenta que ainda que a imensa maioria daqueles que formam esse que seria seu públicoalvo, essa extensas parcelas da sociedade estão cada vez mais inseridas nas redes sociais da internet, como o Facebook, Twitter e You Tube, que ele cita particularmente.

Esse seria o público e esses seriam os canais com os quais e através dos quais as oposições deveriam dialogar, no intuito de mobilizar as forças que na sociedade civil poderiam levá-la a derrotar o lulismo.

Continua seu roteiro de ação das oposições dizendo que elas

precisam voltar às salas universitárias, às inúmeras redes de palestras que se propagam pelo país afora e não devem, obviamente, desacreditar do papel da mídia tradicional: com toda a modernização tecnológica, sem a sanção derivada da confiabilidade, que só a tradição da grande mídia assegura, tampouco as mensagens, mesmo que difundidas, se transformam em marcas reconhecidas. 
Cardoso concorda com Braga e Oliveira em apontar a cooptação dos dirigentes sindicais como fator-chave da hegemonia lulista. Ambos ainda reforçam a crítica do clientelismo que teria se apossado das relações entre Executivo e Legislativo e corroboram na crítica à "adesão progressiva no começo envergonhada e por fim mais deslavada do petismo lulista à nova ordem e a suas ideologias" (CARDOSO, 2011). Coadunam até mesmo na crítica de "que estamos pagando $\mathrm{R} \$ 50$ bilhões por ano para manter reservas elevadas em dólares".

Concorda com Manuel Castells (2013) quando diagnostica que diante do "anacronismo das instituições político-partidárias, seria talvez pedir muito aos partidos que mergulhem na vida cotidiana e tenham ligações orgânicas com grupos que expressam as dificuldades e anseios do homem comum. Mas que pelo menos ouçam suas vozes e atuem em consonância com elas". E ainda mais adiante: "Seres humanos não atuam por motivos meramente racionais. Sem a teatralização que leve à emoção, a crítica moralista ou outra qualquer cai no vazio".

Num trecho de certo tom profético, FHC, em escrito produzido no ano de 2011, antecipa os caminhos da oposição conservadora no junho de 2013:

Talvez as discussões sobre os meandros do poder não interessem ao povo no dia-a-dia tanto quanto os efeitos devastadores das enchentes ou o sufoco de um trânsito que não anda nas grandes cidades. Mas, de repente, se dá um "curto-circuito" e o que parecia não ser "política" se politiza. [...] Obviamente em nosso caso, o de uma democracia, não estou pensando em movimentos contra a ordem política global, mas em aspirações que a própria sociedade gera e que os partidos precisam estar preparados para que, se não os tiverem suscitado por sua desconexão, possam senti-los e encaminhá-los na direção política desejada.

Cardoso professa que o lulismo seria um neopopulismo latino-americano, à maneira do peronismo, baseado no carisma do chefe, no caso o Lula, na distribuição de benefícios sociais, na cooptação dos dirigentes dos movimentos sociais e na subordinação dos sindicatos, através de apadrinhamentos e recursos públicos, bem como das relações clientelistas com o legislativo. Sua superação passaria por entender que no "mundo contemporâneo este caminho não se constrói apenas por partidos políticos, nem se limita ao jogo institucional. Ele brota também da sociedade, de seus blogs, twitters, redes sociais, da mídia e das organizações da sociedade civil, enfim, é um processo coletivo". 


\section{A ASCENSÃO DO SUBPROLETARIADO}

Tanto Cardoso quanto Oliveira e Braga dão excessiva atenção aos aspectos "transformistas" do lulismo, compreendendo-o em determinados momentos como movimento predominantemente de cúpula, um processo conduzido unilateralmente pelos grupos dirigentes que emergiram do sindicalismo dos anos 1970 e 1980. Noutra corrente de interpretação do lulismo, admitindo o deslocamento político e ideológico do PT, André Singer tem em sua análise a vantagem de também compreender o fenômeno de classes que sustenta o lulismo e sua peculiar ideologia.

Singer descreve a trajetória ideológica do petismo pondo em conflito aqueles a que chamou de "as duas almas": "o espírito de Sion" e o "o espírito do Anhembi". O marco do espírito do Anhembi seria a reunião da direção nacional do PT que aprovou o conteúdo da Carta ao Povo Brasileiro, lançada pelo comando da campanha de Lula à presidência, em 22 de junho de 2002. Contudo, Singer aponta que ambas as tendências já se encontravam ativas na fundação do partido no colégio Sion.

\footnotetext{
A alma do Anhembi, expressa no programa "Lula 2002", comprometese com a estabilidade e atira as propostas de mudança radical ao esquecimento. Enquanto a alma do Sion, poucos meses antes, insistia na necessidade de "operar uma efetiva ruptura global com o modelo existente", a do Anhembi toma como suas as "conquistas" do período neoliberal: "a estabilidade e o controle das contas públicas e da inflação são, como sempre foram, aspiração de todos os brasileiros", afirma (SINGER, 2012, p. 97).
}

Os governos petistas expressariam a síntese contraditória das duas almas, que foi possibilitada pela capacidade de "promover, simultaneamente, políticas que beneficiam o capital e a inclusão dos mais pobres, com melhora relativa na situação dos trabalhadores, que permitiu a convivência dos espíritos do Anhembi e do Sion” (ibid, p. 122).

Com efeito, essa alternância ideológica no seio do Partido dos Trabalhadores não se deu - ao contrário do que faz supor as análises de Cardoso, Braga e Oliveira desconectada de movimentos materiais das bases da sociedade brasileira em seu atual estágio de desenvolvimento produtivo e de sua inserção no cenário internacional.

Singer demonstra, com base em séries de pesquisas eleitorais, que o reordenamento ideológico do PT, que avança inicialmente em 2002, com objetivo simples de vencer as eleições, foi realimentado e fortalecido por um realinhamento em que houve o deslocamento das bases eleitorais do petismo, fazendo surgir o lulismo. 
Ainda em 2003, Lula apresentou ao Congresso uma proposta de reforma da Previdência que acabou por extinguir a aposentadoria integral de novos servidores públicos, entre outras medidas consideradas conservadoras, que incomodaram, sobretudo, às camadas médias da sociedade. Por outro lado, a ampliação do crédito consignado, o avanço real do salário mínimo e o Programa Bolsa Família incluíram no consumo milhões de brasileiros que até então não tinham essa perspectiva.

As medidas práticas dos primeiros anos de governo, aliadas à crise do mensalão, sustentaram um duplo deslocamento de bases sociais do petismo, "a classe média se afasta e contingentes pobres ocupam o seu lugar. Isso quer dizer que, embora o processo de mudança tenha começado em 2002, a eleição decisiva do ponto de vista das classes, na qual o subproletariado adere em bloco a Lula e a classe média ao PSDB, é a de 2006." (ibid, p. 14).

Na eleição de 2002, Lula se elegeu com grande apoio dos setores médios da sociedade, com destaque aos funcionários públicos. O discurso da ética era um dos pilares ideológicos dessa composição. A partir da eleição de 2006, o lulismo surge de uma recomposição de classes ou frações de classes. A recomposição se deu via "sobrepopulação trabalhadora superempobrecida permanente", que forma o subproletariado brasileiro.

As camadas subproletárias - a exemplo do que se vê na análise d'O 18 brumário acerca das populações camponesas - pelas condições de sua inserção no modo de produção não possuem os elementos sociais necessários para se organizar enquanto classe; sua ação na política se dá de cima pra baixo, quando uma liderança assume para si o projeto dessa fração de classe e então a mobiliza politicamente.

A ideologia específica desse subproletariado - que tem origens no escravismo colonial brasileiro - é aquela que almeja a melhoria da qualidade de vida, através da inserção no mercado de trabalho, promovida por um Estado forte capaz de preservar as conquistas sem entrar em conflito com o capital, o que na concepção dessas camadas constitui ameaça aos progressos materiais duramente obtidos.

Ao encontrar em Lula o líder capaz de executar esse projeto de diminuição da desigualdade sem conflito com o capital, o subproletariado adere a sua liderança. Assim, o lulismo seria um bloco cuja base social está no subproletariado que deseja prosseguir na redução da pobreza através da inserção no mercado de trabalho, ainda que precária, como se dá. Isso pode ocorrer sem enfrentamentos, porque ao mesmo tempo em que se dá a redução da pobreza, cresce a riqueza dos mais ricos - fenômeno possível pelo crescimento econômico do Brasil, devido, em grande parte, à ação do governo, que teve a perspicácia de 
ativar o mercado interno, via incorporação dos mais pobres, num cenário de expansão do mercado internacional e da demanda por comodities, entre 2003 e 2008, e por programas que ativaram amplos contingentes de mão de obra, como o "Minha Casa, Minha Vida".

Assim, o lulismo seria um reformismo fraco, baseado no projeto de redução da pobreza sem confronto político aberto, sobretudo com o mercado. A pobreza recua de forma lenta, mas sem conflitos que ameacem o apoio das camadas mais pobres ao governo. A desigualdade também cai, ainda que mais lentamente.

O lulismo teve ainda amplas consequências no mundo rural. "No Brasil, há inúmeras indicações de que as massas agrárias também estiveram tradicionalmente sob o domínio dos grandes proprietários rurais.” (SINGER, 2012, p. 42).

Singer concorda que o lulismo tem sérias implicações na luta de classes e na autoorganização do proletariado. Ao polarizar pobres contra ricos, ele relega a luta de classes e a relação capital/trabalho ao segundo plano. Promove um equilíbrio delicado e constantemente renovado entre os interesses do grande capital e das camadas subproletárias. Mantém um estado de suspensão em que nem avançam consideravelmente as reformas progressistas, que ampliem os direitos trabalhistas, a exemplo da redução da jornada de trabalho, nem avançam, como antes, com a desregulamentação e a precarização do trabalho.

Contudo, Singer especula se o lulismo não seria capaz de conduzir a luta de classes a um novo patamar. Parte da compreensão dos significados da existência desse subproletariado que em nosso país tem por característica o superempobrecimento e a permanência. "É mister, portanto, reconhecer que o conflito de classes está condicionado no Brasil pela existência de uma vasta fração de classe que luta por aceder ao trabalho formal em regime capitalista, com todos os defeitos que ele possui, tendo estado historicamente dele excluída."(ibid, p. 44).

Essa existência que deve ser reconhecida implicou contraditoriamente no domínio da burguesia sobre o proletariado, uma vez que incapazes de se auto-organizar as camadas subproletárias foram historicamente dirigidas por cima, através do Estado. O dado novo representado pelo lulismo é a ascensão de amplas parcelas dessas camadas ao trabalho formal, expandindo o proletariado brasileiro, engendrando uma população que, uma vez inserida no consumo, passa a desejar a ampliação de seu poder econômico e novos direitos até então não almejados de forma prática e imediata.

O "lulismo tem um pertencimento de classe específico, cuja prioridade, conforme vimos, é a diminuição da pobreza, e não da desigualdade", daí que "o reformismo fraco é o 
projeto adotado pelo bloco no poder. Expansão do mercado interno, com integração do subproletariado ao proletariado via emprego (mesmo que precário), consumo e crédito, sem reformas anticapitalistas, e com lenta queda da desigualdade como subproduto, é o que se deve esperar" (ibid, p. 200).

O lulismo, portanto, traz em si tendências contraditórias, que Singer bem descreve no seguinte trecho:

Essa situação carrega um paradoxo: o de que a esquerda no Brasil ganhou e perdeu, ao mesmo tempo, com a ascensão do lulismo. No momento em que um projeto reformista, mesmo fraco, avança na redução da sobrepopulação trabalhadora superempobrecida permanente, aumentando o contingente proletário, a luta ideológica parece recuar para um estágio anterior ao conflito capital/trabalho. (ibid, p. 219)

\section{NOVA CLASSE MÉDIA?}

São cada vez mais frequentes as referências à nova classe média, e, por mais casual que o uso de tal conceito pareça ser, traz implícita determinada compreensão da dinâmica de classes no Brasil contemporâneo que cabe aqui perscrutar.

Parto da hipótese de Singer de que o lulismo é

o encontro de uma liderança, a de Lula, com uma fração de classe, o subproletariado, por meio do programa cujos pontos principais foram delineados entre 2003 e 2005: combater a pobreza, sobretudo onde ela é mais excruciante tanto social quanto regionalmente, por meio da ativação do mercado interno, melhorando o padrão de consumo da metade mais pobre da sociedade, que se concentra no Norte e Nordeste do país, sem confrontar os interesses do capital. (SINGER, 2012, p. 1516)

Assim, compreende-se que essa parcela gigantesca da população brasileira entra na cena política a partir de seu encontro com um líder que possui um projeto político compatível com sua ideologia e força capaz de mobilizá-la por cima.

Lembrando Tocqueville, Singer comenta que as revoltas costumam acontecer nos momentos em que avançam as condições de vida, em que a expectativa de melhoras se acentuam, não em momentos de profunda depressão como alguns querem nos fazer crer.

Em 2013, pela primeira vez na história, o contingente de trabalhadores com carteira assinada superou o de empregados na informalidade, nos maiores centros urbanos do país. Diante dessa incorporação massiva, tem grande valor a sugestão de que "deve-se 
imaginar que o novo proletariado brasileiro, beneficiado pela ascensão do lulismo, passe a fazer reivindicações." (ibid, p. 220).

Nos Movimentos de Junho, episódio de relevância para a compreensão da política brasileira contemporânea, podemos ter nos defrontado com a expressão desses anseios do novo proletariado, recém egresso das camadas subproletárias, que agora passaria a reivindicar direitos até então tidos como distantes, uma vez que a própria subsistência material mais básica era constantemente posta em risco, diante da precariedade dos vínculos empregatícios e sua característica rotatividade. Assim demandas como a ampliação do alcance e a melhoria da qualidade dos serviços públicos puderam vir à tona na voz dessas camadas emergentes.

Contudo, ao que nos parece, as bandeiras históricas do proletariado tiveram pouca presença nas jornadas de junho. Exemplo disso, a PEC da redução da jornada de trabalho para 40 horas semanais, sem redução dos salários, esteve praticamente ausente do debate público até o dia 11 de julho, quando foi resgatada e logo a seguir novamente esquecida; já questões carregadas de valorações morais como a PEC 37 dominaram a agenda pública. E, como nos alertava o ex-presidente sociólogo, são as classes médias as mais sensíveis ao "discurso ético" que desde a crise do mensalão virou o centro do programa oposicionista.

Marilena Chauí (2011) pertence aos que rejeitam a hipótese do surgimento de uma nova classe média brasileira; para ela, o que surgiu das transformações pelas quais passou o país sob o lulismo foi uma nova classe trabalhadora, sobredeterminada pelas intimações do capitalismo em sua face neoliberal.

A reestruturação produtiva típica do capitalismo tardio tende a converter parcela significativa da força de trabalho em prestação de serviços, muitas vezes tomando a mão de obra o status de empresas informais, fenômeno reforçado pela ampliação do exército industrial de reserva, que é inflado pelos incrementos na produtividade do trabalho. Assim vemos o "ressurgimento de formas arcaicas de exploração, tais como empresas familiares e trabalho a domicílio. Essas formas muitas vezes são estimuladas por capitais monopólicos, que demitem operários para subcontratar seus serviços como fornecedores externos." (SINGER, 1982, p. XXII).

Estas e outras conformações do capitalismo tardio, a exemplo da incorporação da tecnociência aos processos produtivos, impuseram renovado desafio à compreensão marxista das classes sociais. Para superar as dificuldades surgidas e possibilitar o avanço da interpretação da dinâmica de classes no Brasil contemporâneo, Chauí assume uma 
definição de classe análoga à de Nicos Poulantzas, para quem as "classes sociais são conjuntos de agentes sociais determinados principalmente, mas não exclusivamente, por seu lugar no processo de produção, isto é, na esfera econômica.” (1978, p. 13-14). O proletariado, nesta concepção, não existiria fora da luta de classes, podendo nela se inserir, mas apenas seria uma classe no processo real de seu enfrentamento contra a burguesia.

Chauí vai se valer desta concepção para desenvolver uma conceituação abrangente, porém mais bem delimitada, da classe média, partindo da definição marxista clássica da pequena-burguesia, que seria o estrato social posicionado em lugar intermediário às classes fundamentais do capitalismo - a burguesia e o proletariado - de forma que a classe média "situava-se nas chamadas profissões liberais, na burocracia estatal (ou nos serviços públicos) e empresarial (ou na administração e gerência), na pequena propriedade fundiária e no pequeno comércio." (CHAUÍ, 2013, p. 129).

Certa sociologia, notadamente a de inspiração norte-americana, propõe classificar as classes sociais com base na renda. Desta forma, pode ela criar a ilusão de uma mobilidade social que se verificaria no caso brasileiro pela formação daquilo a que vem se chamando "nova classe média". Rejeitando essa hipótese, Chauí vai mais longe, elucidando o caráter ideológico conservador de seu conteúdo e denunciando o fenômeno a que Márcio Pochmann caracterizou como "a opção política rasteira que certos intelectuais engajados à lógica mercantil se associam com uma retórica de classe de rendimento desprovida de qualquer sentido estrutural, o que nada mais é do que a tradução do caráter meramente propagandista dos imperativos do mercado." (POCHMANN, 2012, p. 7).

Ambos os autores em que este trabalho se baseia para explicar a dinâmica de classes do Brasil atual - Singer, Chauí e Pochmann - concordam que as parcelas que ascenderam economicamente sob o lulismo se incorporam à classe trabalhadora, que excedendo os limites do operariado industrial e agrícola, se torna crescentemente complexa e heterogênea.

Distinguir a nova classe trabalhadora da classe média requer diversos esforços metodológicos. É preciso compreender que distinções de renda, propriedade (casa própria, automóvel etc) e escolaridade não justificam a clivagem de classes. As transformações anteriormente explicitadas implicam que mesmo trabalhadores autônomos, ainda que organizados em empresas particulares, podem se constituir em força de trabalho, dado o crescente processo de terceirização e subcontratação. $O$ mesmo vale para pequenas propriedades que podem estar sujeitas a relações de exploração por parte dos oligopólios transnacionais. É crescente, por exemplo, o número de professores de instituições privadas 
de ensino superior que se constituem em pessoa jurídica e deixam de ser empregados, passando à rubrica de prestadores de serviços.

Excluídos todos esses casos de novos trabalhadores do capitalismo tardio, restariam "as burocracias estatal e empresarial, o serviço público, a pequena propriedade fundiária e o pequeno comércio não filiado às grandes redes de oligopólios transnacionais como espaços para alocar a classe média.” (CHAUÍ, 2012, p. 130).

"Estando fora do núcleo econômico definidor do capitalismo, a classe média encontra-se também fora do núcleo do poder político [...] Isso a coloca numa posição que a define menos por sua posição econômica e muito mais por seu lugar ideológico, e este tende a ser contraditório.” A classe média, vivendo entre o medo de descer à condição proletária e o sonho de ascender ao status dominante, "tende a alimentar o imaginário da ordem e da segurança", o que faz com que seu papel social e político seja "o de assegurar a hegemonia da classe dominante, fazendo com que essa ideologia, por intermédio da escola, da religião, dos meios de comunicação, se naturalize e se espalhe por toda a sociedade.” Nos casos em que os agentes de determinadas parcelas da classe média aderem a um conteúdo ideológico anticapitalista, partem "via de regra, para a extrema esquerda e o voluntarismo." Predominantemente, é a ideologia da ordem e da segurança que constitui a prática social e política da classe média. "É sob essa perspectiva que se pode dizer que a classe média é a formadora da opinião social e política conservadora e reacionária.” (ibid, p. 131).

Desempenhando seu papel de formadora do pensamento conservador e reacionário, a "classe média tradicional constitui o suporte de massa da coalizão rentista" (SINGER, 2012, p. 264), liderada pelo capital financeiro nacional e internacional. Não à toa, Cardoso (2011) defende, em seu artigo, que o PSDB, principal partido da coalizão rentista, eleja as camadas médias da sociedade como público preferencial de sua intervenção política. Cardoso propõe envolver no debate oposicionista

toda uma gama de classes médias, de novas classes possuidoras (empresários de novo tipo e mais jovens), de profissionais das atividades contemporâneas ligadas à ti (tecnologia da informação) e ao entretenimento, aos novos serviços espalhados pelo Brasil afora, às quais se soma o que vem sendo chamado sem muita precisão de "classe c" ou de nova classe média.

As reiteradas tentativas de inserir as novas camadas de trabalhadores mobilizadas sob o lulismo numa amorfa classe média não são despropositadas. Ao defender uma identidade de classe baseada no consumo, tal discurso cria uma força atrativa sobre a classe 
trabalhadora, no sentido de sua absorção à ideologia dominante e à internacionalização de sentidos baseados nos valores do mercado. Ainda, o aparecimento de uma nova classe média "é menos perigoso para a ordem estabelecida do que uma classe trabalhadora protagonista social e política." (CHAUÍ, 2012, p. 130).

Outra característica fundante de nossa classe média é determinada pela "estrutura autoritária da sociedade brasileira". Tendo origem já no escravismo colonial brasileiro, a marca da sociedade brasileira é o "predomínio do espaço privado sobre o público e, tendo o centro na hierarquia familiar, é fortemente hierarquizada em todos os seu aspectos: nela, as relações sociais e intersubjetivas são sempre realizadas como relação entre um superior, que manda, e um inferior, que obedece." (ibid, p. 131).

Divergindo de Singer que vê "indícios de que possa ter havido achatamento nos ganhos da classe média" (2012, p. 142), Chauí afirma: "No Brasil, esta se beneficiou com as políticas econômicas dos últimos dez anos, também cresceu e prosperou.” (2012, p. 130). Sua oposição ao lulismo se daria, portanto, muito mais devido a suas conformações ideológicas que por perdas materias sensíveis. Nisso concorda também Singer, para quem a “rejeição da pequena burguesia às políticas de inclusão, que ela julga financiar com seus impostos, se intensifica conforme a ascensão dos pobres relativiza a superioridade social da classe média.” (SINGER, 2012, p. 164). Essa percepção de perda da distinção social e o sentimento de proximidade crescente das camadas trabalhadoras, ainda que por ascensão destas e não por sua regressão, atinge os brios da classe média que, do ponto de vista simbólico,

substitui a falta de poder econômico e de poder político, que a definem, seja pela guinada ao voluntarismo de esquerda, seja voltando-se para a direita pela busca do prestígio e dos signos de prestígio, como os diplomas e os títulos vindos das profissões liberais, e pelo consumo de serviços e objetos indicadores de autoridade, riqueza, abundância, ascensão social - a casa no "bairro nobre" com quatro suítes, o carro importado, a roupa de marca etc. Em outras palavras, o consumo the aparece como ascensão social em direção à classe dominante e como distância intransponível entre ela e a classe trabalhadora. Esta, por sua vez, ao ter acesso ao consumo de massa tende a tomar esse imaginário por realidade e a aderir a ele. (CHAUÍ, 2012, p. 132).

Ocorreu ainda que a classe trabalhadora passou, através da inserção no mercado de trabalho formal e dos programas de redistribuição de renda, a poder exigir mais. Fica cada vez mais difícil encontrar nas cidades trabalhadores dispostos a pesados e insalubres serviços informais com remuneração irrisória, como era tão comum há pouco tempo. 
Ressurgem os mitos sobre a preguiça nata do povo brasileiro. A redução do nível do desemprego, que na casa de 5,4\% está próximo ao que se considera pleno emprego na economia, fortaleceu a capacidade reivindicatória da parcela mais pobre da população e seu poder de barganha nas negociações trabalhistas.

A classe média, herdeira dos hábitos senhoriais, desde sempre acostumada à farta disponibilidade de serviçais, começa a sentir os impactos dessa ainda que lenta promoção social dos pobres brasileiros. Demonstração disso foi sua reação histérica diante da regulamentação profissional das empregadas domésticas. Apelou-se à ameaça do desemprego em massa no setor e à invasão do Estado nas relações quase familiais entre patrões e empregados domésticos, argumento que logo nos remete a certa visão romântica de nossa formação social que preencheu de afeto e paternalismo as cruéis relações sociais do escravismo colonial brasileiro, num claro esforço legitimador da opressão senhorial. $\mathrm{O}$ que está em cena, contudo, é a sensação da classe média de que perde privilégios e distinção social.

"Sensível à argumentação empresarial de que a carga tributária no Brasil é excessiva, a pequena burguesia tende a constituir o esteio de massa dos movimentos por redução dos impostos." (SINGER, 2012, p. 204) Não à toa, críticas ao excesso de gastos do Estado, mesmo os investimentos na Copa do Mundo, tiveram ressonância nos protestos de 2013.

A classe média constitui, desta forma, o lastro social de uma coalizão rentista, da qual é a formuladora de sua ideologia particular, caracterizada pela fé no mercado e rejeição à presença do Estado nos processo produtivos e nas relações econômicas; na meritocracia e na consequente desaprovação das políticas públicas de redução das desigualdades e inclusão social, e, ainda, no destacado descontentamento com a ascensão social dos mais pobres, que seriam destinados à vida de serviçais; pela defesa da ordem e da segurança.

Em outro campo político e social, atua a "coalizão produtivista" que comporta em aliança delicada os industriais e os trabalhadores. Para Singer essa

frente teria como programa controlar a entrada e saída de capital estrangeiro e diminuir os juros, cuja elevação, como já vimos, encarece os investimentos produtivos e desvaloriza o real, barateando as importações e ameaçando as cadeias produtivas internas. Além disso, interessa à coalizão elevar substancialmente a taxa de investimento público em infraestrutura, tornando mais baratas as atividades produtivas. Tal aumento poderia ocorrer usando recursos públicos poupados por diminuição significativa dos juros. (2012, p. 161) 
A motivação da classe operária na defesa de tal programa está em que "a morte da indústria nacional representa a sua própria desaparição enquanto classe e a regressão a um modelo colonial que não comporta segmento industrial extenso e sofisticado." (idem). Contudo, tal composição não está isenta de contradições. Se, de um lado o operariado depende da capacidade de intervenção do Estado para ver efetivadas suas expectativas de acesso a serviços básicos com qualidade, como educação, saúde etc, do outro, é nítido o interesse do capital em reduzir a carga tributária.

A essa equilíbrio instável sobrepõe-se outro:

Embora à classe trabalhadora interesse a redução da sobrepopulação trabalhadora superempobrecida permanente, cuja existência deprime as condições de luta, o lulismo tem um pertencimento de classe específico, cuja prioridade, conforme vimos, é a diminuição da pobreza, e não da desigualdade. Por isso, o reformismo fraco é o projeto adotado pelo bloco no poder. Expansão do mercado interno com integração do subproletariado via emprego (mesmo que precário), consumo e crédito, sem reformas anticapitalistas, e com lenta queda da desigualdade como subproduto, é o que se deve esperar. (SINGER, 2012, p. 200).

\section{CONCLUSÕES PROVISÓRIAS}

A proposição de Singer de uma coalizão produtivista, apesar de ter bases teóricas na estrutura da sociedade brasileira, efetivamente não teve vez nos processos políticos concretos. Quando muito, foi a expressão de certos interesses convergentes, a exemplo do controle de fluxos de capital estrangeiro, da redução das taxas de juros e dos investimentos em infraestrutura. Contudo, tal convergência, como nota o próprio Singer, não deixou de existir em contradição flagrante. Se, de um lado, interessa ao capital industrial a redução dos juros, pois implica em aumento da demanda no mercado interno, por outro, o caráter articulado do capital contemporâneo, que existe tanto no processo produtivo quanto no especulativo, induz também ao interesse em lucrar com a alta da taxa de juros. As grandes empresas nacionais não apenas negociam suas ações nas bolsas, como nelas investem seus proprietários. Assim, o capital encontra facilidade ao migrar de uma esfera à outra. Neste ponto, concordamos com Braga quando defende que o essencial ao capital - seja ele produtivo ou financeiro - é a manutenção das condições de máxima exploração, o rebaixamento dos níveis salariais e a degradação das condições de trabalho. De fato, existem necessidades que tendem a convergir os interesses de trabalhadores e industriais. Mas as tendências em contrário, igualmente sustentadas na estrutura social, em muito as 
sobrepujam, de forma que cremos que a coalizão produtivista proposta por Singer não tem efetividade.

Quer transformismo, quer populismo ou reformismo fraco, as hipóteses sobre o fenômeno dos governos petistas deste início de século esbarram na subestimação do papel da classe trabalhadora tradicional na sustentação do projeto político das forças hoje alojadas no governo. Tal presença se evidencia no efetivo apoio de uma vasta rede de sindicatos, organizados, sobretudo no âmbito da Central Única dos Trabalhadores. Pochmann (2012) já evidenciava que este não é o primeiro ciclo de crescimento econômico das últimas décadas. Entre os anos 1960 e 1970, tivemos acentuado crescimento da produção, sem, contudo, redundar em diminuição das desigualdes nos níveis de renda. Após cerca de vinte anos de crescimento econômico irrisório, o Brasil viveu uma nova década de ascensão nos anos 2000. Desta vez, contudo, com lenta, mas real redução das desigualdades. Sabendo-se que a tendência de enriquecimento da parcela mais rica da população permaneceu durante o período, podemos deduzir que a redução das desigualdades se dá por um ritmo mais acelerado de ampliação da renda das camadas mais pobres em relação às classes médias, incluídos aí os trabalhadores com renda superior a 1,5 salários mínimos. Acreditamos que isto seja indício suficiente para se propor que tal presença da classe trabalhadora tradicional na base social de sustentação política do lulismo nem se dê, a exemplo das reações antes apontadas nas camadas médias, sem que haja contradições.

As críticas de Braga e Oliveira que vão ao sentido de identificar, como resultado do lulismo, uma despolitização da vida nacional, gerando um governo de arbítrio, não levam em conta a própria realidade do Estado contemporâneo, sobredeterminado por profundas alterações nas estruturas sociais e fruto de séculos de lutas de classes. Conforme vemos em Poulantzas (2000), o Estado não limita sua atuação ao exercício da violência em última instância, é não só presente nas relações de produção como ativo na manutenção da coesão social. Se o Estado brasileiro sob o lulismo parece assumir as formas de uma solução de compromisso, não é apenas pela ação voluntária das direções petistas, transformistas ou não; é condição da própria constituição do Estado contemporâneo.

Outro aspecto que parece negligenciado pelos autores é o da tendência na criação de novos empregos que concentra 9 em cada 10 novos postos no setor de serviços. Seguindo a tendência verificada em todo o mundo, esta expansão via setor terciário muda não apenas os níveis de renda, como também a identificação de classe de extensas parcelas das camadas trabalhadoras. Não se pode classificar o conjunto dos trabalhadores no setor 
terciário na categoria de subproletariado ou precariado. Muitos destes trabalhadores resistem à alta rotatividade da ocupação inerente deste setor e criam identidade e laços de solidariedade que não convergem para as organizações tradicionais da classe trabalhadora na sociedade civil. O subproletariado de Singer funciona bem ao analisar as camadas mais pobres do Nordeste brasileiro, por exemplo; já o precariado de Braga tem forte potencial explicativo sobre as camadas de profissionais jovens submetido à alta rotatividade e à ideologia da qualificação e reciclagem características do projeto neoliberal. Mas cremos que ambas falham ao compreender os interesses próprios e a cultura política e organizativa desta parcela dos trabalhadores que, segundo dados de 2008 do Instituto Brasileiro de Geografia e Estatísticas, equivale a 57,6\% do total de postos de trabalho no Brasil.

É pouco realista exigir dos intérpretes do lulismo que esgotem as possibilidades explicativas de um momento histórico ainda em curso, e, portanto, em construção e disputa. Se é fato que houve uma reorientação ideológica do Partido dos Trabalhadores ao longo dos primeiros anos deste século, é insuficiente postular que daí surgem todas, ou mesmo as principais, explicações para o fenômeno do lulismo. As transformações no capitalismo mundial que passaram a repercutir mais amplamente no Brasil, e de forma condicionada pela correlação de forças resultante, após a abertura política na década de 1980, talvez só agora comecem a manifestar o essencial de suas implicações políticas e sociais. Há nas bases do lulismo muito mais que carisma e capitulação de classe. A compreensão do comportamento político e da organização na sociedade civil desta nova e ascendente classe trabalhadora talvez seja o elemento heurístico a fazer avançar nosso entendimento acerca dos processos políticos do Brasil contemporâneo.

\section{REFERÊNCIAS BIBLIOGRÁFICAS}

BRAGA, R. 2012. A política do precariado: do populismo à hegemonia lulista. São Paulo: Boitempo.

BRAGA, R. 2013. Sob a sombra do precariado. In: MARICATO, Ermínia et al. Cidades rebeldes: passe livre e as manifestações que tomaram as ruas do Brasil. São Paulo: Boitempo, 2013.

CARDOSO, F. H. 2011.O papel da oposição. Revista Interesse Nacional. Ano 4, no 13, abr. jun. Disponível em < http://interessenacional.uol.com.br/index.php/ edicoes-revista/opapel-da-oposicao/ $>$. 
CASTELLS, M. 2013. Redes de indignação e esperança: movimentos sociais na era da internet. Tradução de C. A. Medeiros. Rio de Janeiro: Zahar.

CHAUÍ, M. 2013. Uma nova classe trabalhadora. In: SADER, Emir (Org.). 10 anos de governos pós-neoliberais no Brasil: Lula e Dilma. São Paulo: Boitempo.

OLIVEIRA, F. de. 2003. Crítica à rąãa dualista/o ornitorrinco. São Paulo: Boitempo, 2003.

OLIVEIRA, F. de. 2010. O avesso do avesso. In: et al (Orgs). Hegemonia às avessas: economia, política e cultura na era da servidão financeira. São Paulo: Boitempo.

POCHMANN, M. 2012. Nova classe media?: o trabalho na base da pirâmide social brasileira. São Paulo: Boitempo.

POULANTZAS, N. 1978. As classes sociais no capitalismo de hoje. 2. ed. Rio de Janeiro: Zahar.

POULANTZAS, N. 2000. O Estado, o poder, o socialismo. 4. ed. Traduzido por Rita Lima. São Paulo: Paz e Terra.

SINGER, A. 2012. Os Sentidos do Lulismo - Reforma gradual e pacto conservador. São Paulo: Companhia das Letras.

SINGER, P. 1982. Apresentação. In: MANDEL, E. O capitalismo tardio. São Paulo: Abril. 